\title{
EFEKTIFITAS KOMPOS DAUN MENGGUNAKAN EM4 DAN KOTORAN SAPI
}

\author{
Nunik Ekawandani ${ }^{1)}$; Alvianingsih ${ }^{2)}$ \\ 1), 2)Teknik Kimia, Politeknik TEDC \\ E-mail: ekawandani@poltektedc.ac.id ${ }^{1)}$
}

\begin{abstract}
Abstrak
Penelitian ini dilakukan untuk mengetahui efektivitas penggunaan EM4 dengan kotoran sapi dalam pembuatan kompos sampah organik. Kompos sendiri sangat bermanfaat sebagai pupuk alami. Petani di Indonesia masih banyak menggunakan pupuk kimia dalam perawatan tanaman pertanian mereka. Padahal bahan baku untuk membuat pupuk kompos ada disekitar mereka. Sekiranya perlu peran pemerintah dalam penggunaan bahan yang ramah terhadap lingkungan dan juga terhadap bahan pangan. Bahan pembuatan pupuk organik atau pupuk kompos berupa pemanfaatkan limbah pertanian, seperti jerami, daun-daunan, rumput, pupuk kandang, dan lain-lain. Pengomposan dapat di lakukan dengan mengunakan aktivator EM4 dan kotoran sapi. Hasil penelitian menunjukkan untuk kompos yang menggunakan aktivator EM4 mengandung $P$ sebesar $0,12 \%, \mathrm{~K}$ sebesar $0,47 \%$ dengan rasio $\mathrm{C} / \mathrm{N} 25$, tidak memenuhi standar kompos SNI 197030-2004, sedangkan pupuk kotoran sapi mengandung $\mathrm{P}$ sebesar $0,21 \%$, $\mathrm{K}$ sebesar $0,44 \%$, dengan nilai rasio $\mathrm{C} / \mathrm{N} 20$, maka dapat disimpulkan bahwa perbandingan pupuk kompos yang menggunakan kotoran sapi lebih memenuhi standar dibandingkan dengan aktivator EM4.
\end{abstract}

Kata kunci: pupuk, kompos, EM4, kotoran sapi

\begin{abstract}
This study was conducted to determine the effectiveness of EM4 use with cow manures in the manufacture of organic waste compost. Compost itself is very useful as a natural fertilizer. Farmers in Indonesia still use a lot of chemical fertilizers in the care of their agricultural crops. Whereas raw materials to make compost is around them. If necessary the role of government in the use of materials that are environmentally friendly and also to food. The material for making organic fertilizer or compost fertilizer is utilization of agricultural waste, such as straw, leaves, grass, manure, and others. Composting organic waste can be done by using EM4 activator and cow manures. The result showed that for compost using EM4 activator containing $P 0,12 \%, K$ $0,47 \%$ with C / N ratio 25, did not fulfill SNI standard of 197030-2004, while cow dung manure contain $P$ equal to $0,21 \%, K$ of $0.44 \%$, with the $C / N$ ratio of 20 , it can be concluded that the compost fertilizer composition using cow dung meets the standard compared to the EM4 activator.
\end{abstract}

Keywords: fertilizer, compost, EM4, cow manures

\section{PENDAhUluan}

Pemanfaatan sampah organik sudah banyak dilakukan dan dimanfaatkan untuk kebutuhan di pertanian atau sebagai sumber biogas. Dipertanian sampah organic yang berupa dedaunan, tanaman sisa panen, jerami dll, dijadikan sebagai bahan pembuatan pupuk kompos. Pupuk ini digunakan sebagai pupuk penyubur tanah di awal penanaman. Ataupun diperjual belikan sebagai penyubur tanah di lahan terbuka lainnya.

Sampah organik adalah sampah yang banyak dihasilkan oleh rumah tangga, pasar, pertanian, maupun industri dll. Sehingga pemanfaatan sampah organik sangat berpeluang besar karena banyaknya bahan baku di lingkungan.

Penggunaan Mikro organisme seperti Effektivitas Migroorganisme (EM4)[/B] merupakan bahan stater untuk membangun pertanian akrab lingkungan dengan memanfatkan mikro organisme pembusuk yang bermanfaat untuk kesuburan tanah, dengan cara pembuatan kompos pupuk kandang dengan menggunakan
EM4 atau sejenisnya, sesuai dengan dosis atau pemakaian yang tepat berdasarkan petunjuk penggunaan. Berdasarkan hal tersebut di atas maka organisme di dalam tanah akan tumbuh subur kembali, sehingga fisik tanah yaitu tektur dan struktur menjadi lebih baik, tanaman akan tumbuh subur, dengan produktifitas yang tinggi (BBPP Lembang 2013).

\section{LANDASAN TEORI}

Pengertian EM4 menurut Kartika (2013:16) adalah pupuk berbentuk cairan yang terdiri atas suatu kultur campuran berbagai mikroorganisme bermanfaat dan menyuburkan tanah.

Kandungan di dalam EM4 menurut Indriani $(2011: 37,38)$ terdiri dari:

1. Bakteri fotosintetik merupakan bakteri bebas yang dapat mensintesis senyawa nitrogen, gula, dan subtansi bioaktif lainya. Hasil metabolit yang diproduksi dapat diserap secara langsung oleh tanaman dan tersedia sebagai substrat untuk perkembangbiakan mikroorganisme yang menguntungkan. 
2. Lactobacillus sp. (bakteri asam laktat), merupakan bakteri yang memproduksi asam laktat sebagai hasil penguraian gula dan karbohidrat lain. Bakteri ini berkerja sama dengan bakteri fotosintesis dan ragi dalam melakukan penguraian. Asam laktat merupakan bahan sterilisasi yang kuat dan dapat menekan mikroorganisme berbahaya dan dapat menguraikan bahan organik dengan cepat.

3. Strepmyces sp, mengeluarkan enzim streptomisin yang bersifat racun terhadap hama dan penyakit yang merugikan. Strepmyces sp. Terbagi menjadi dua golongan, yaitu:

a. Ragi memproduksi substansi yang berguna bagi tanaman dengan cara fermentasi. Substansi bioaktif yang dihasilkan oleh ragi berguna untuk pertumbuhan sel dan pembelahan akar. Ragi ini berperan dalam perkembangbiakan atau pembelahan atau mikroorganisme menguntungkan lain seperti Actinomycetes dan bakteri asam laktat.

b. Actinomycetes merupakan organisme peralihan antara bakteri dan jamur yang mengambil asam amino dan zat serupa yang di produksi bakteri fotosintesis dan mengubah nya menjadi antibiotik untuk mengendalikan patogen. Selain itu, organisme ini menekan jamur dan bakteri berbahaya dengan cara menghancurkan khitin, yaitu zat ensesial untuk pertumbuhan yang dimiliki oleh jamur dan bakteri berbahaya tersebut. Actinomycetes juga dapat menciptakan kondisi yang baik bagi perkembangan mikroorganisme lain.

Manfaat EM4 menurut Indriani (2011:39) dalam proses fermentasi bahan organik, mikroorganisme akan bekerja dengan baik bila kondisi sesuai. Proses fermentasi akan berlangsung dalam kondisi anaerob, $\mathrm{pH}$ rendah (3-4), kadar garam dan gula tinggi, kandungan air sedang 30-40\%, kandungan antioksidan dari tanaman rempah dan obat, adanya mikroorganisme fermentasi, serta suhu yang mendukung $\left(40-50 \%{ }^{\circ} \mathrm{C}\right)$.

Kotoran sapi menurut Harapan (2000:20) Sapi merupakan jenis ternak ruminansia yang relatif lebih digemari oleh masyarakat umum. Tumpukan kotoran sapi yang membusuk adalah sebuah titik perubahan dalam daur nitrogen. Kotoran sapi mengandung sejumlah besar nitrogen yang terkait dalam protein yang ada dalam bagian-bagian tumbuhan yang dimakan sapi. Berbagai bakteri melepaskan nitrogen ini dengan menguraikan protein menjadi senyawasenyawa yang lebih sederhana dan akhirnya menjadi nitrat yang dapat diserap tumbuhan melalui akar.
Pupuk organik adalah pupuk yang berasal dari sisa-sisa tanaman, hewan atau manusia seperti pupuk kandang, pupuk hijau, dan kompos baik berbentuk cair maupun bentuk padat. Dalam Permentan NOMOR28/PERMENTAN/SR. 130/5/2009, disebutkan bahwa pupuk organik adalah pupuk yang sebagian besar atau seluruhnya terdiri dari bahan organik yang berasal dari tanaman dan hewan yang telah mengalami proses rekayasa, dapat berbentuk padat atau cair yang digunakan untuk mensuplai bahan organik, memperbaiki sifat fisik, kimia, dan biologi tanah.

Kompos menurut Suryati (2014:23). Kompos merupakan pupuk yang dibuat dari sampah organik yang sebagian besar berasal dari rumah tangga. Sebetulnya, kompos merupakan pupuk warisan alam yang sudah dikenal nenek moyang kita, tetapi kita lupa untuk memanfatkannya. Kompos adalah bahan organik yang bisa lapuk, seperti daun-daunan, sampah dapur, jerami, rumput dan kotoran lain, yang semua itu berguna untuk kesuburan tanah.

Dengan demikian, pengomposan adalah proses dimana bahan organik mengalami penguraian secara biologis, khususnya oleh mikroba-mikroba yang bermanfaat bahan organik sebagai suber energi. Pada dasarnya pengomposan berlangsung secara alami. Seluruh limbah organik dapat di komposkan, seperti limbah organik rumah tangga, sampah-sampah organik pasar atau kota, kertas, kotoran/limbah peternakan, limbah-limbah pertanian, limbahlimbah agro industri, limbah pabrik kertas, limbah pabrik gula, limbah pabrik kelapa sawit dll.

Tabel 1. Kandungan rata-rata unsur hara dalam kompos

\begin{tabular}{|l|c|}
\hline Komponen & $\begin{array}{c}\text { Kandungan } \\
(\mathbf{\%})\end{array}$ \\
\hline Air & $41,00-43,00$ \\
\hline $\mathrm{C}$ - organik & $4,83-8,00$ \\
\hline $\mathrm{N}$ & $0,10-0,51$ \\
\hline $\mathrm{P}_{2} \mathrm{O}_{5}$ & $0,35-1,12$ \\
\hline $\mathrm{K}_{2} \mathrm{O}$ & $0,32-0,80$ \\
\hline $\mathrm{Ca}$ & $1,00-2,09$ \\
\hline $\mathrm{Mg}$ & $0,10-0,19$ \\
\hline $\mathrm{Fe}$ & $0,05-0,64$ \\
\hline $\mathrm{Al}$ & $0,50-0,92$ \\
\hline
\end{tabular}

Faktor yang mempengaruhi proses pengomposan menurut Budi Nining Widarti, (2015, 77 - 78) Rasio C/N, Ukuran partikel, Aerasi, Porositas, Kelembaban (Moisture content), Temperatur, Derajat keasaman $(\mathrm{pH})$, Kandungan hara.

Teknologi pengomposan sampah sangat beragam baik secara aerob maupun anaerob, dengan atau tanpa aktivator pengomposan. Pada pengomposan secara aerob dan proses dekomposisi akan berlangsung optimal jika ada 
oksigen. Sementara, proses anaerob berlangsung optimal jika tidak terdapat oksigen. Aktivator merupakan bahan yang terdiri atas enzim, asam humat, dan mikroorganisme (kultur bakteri) yang berfungsi untuk mempercepat proses pengomposan. Proses anaerob merupakan suatu proses biokimia dimana reaksinya berlangsung tanpa kehadiran oksigen.

Tabel 2. Standar kualitas kompos

\begin{tabular}{|c|c|c|c|c|}
\hline No. & Parameter & Satuan & Min & Maks \\
\hline 1. & Kadar air & $\%$ & - & 50 \\
\hline 2. & Temperatur & ${ }^{0} \mathrm{C}$ & & $\begin{array}{c}\text { Suhu air } \\
\text { tanah }\end{array}$ \\
\hline 3. & Warna & & & Kehitaman \\
\hline 4. & Bau & & & $\begin{array}{c}\text { Berbau } \\
\text { tanah }\end{array}$ \\
\hline 5. & Ukuran partikel & $\mathrm{Mm}$ & 0,55 & 25 \\
\hline 6. & $\begin{array}{l}\text { Kemampuan ikat } \\
\text { air }\end{array}$ & $\%$ & 58 & - \\
\hline 7. & $\mathrm{Ph}$ & & 6,80 & 7,49 \\
\hline 8. & Bahan asing & $\%$ & $*$ & 1,5 \\
\hline \multicolumn{5}{|c|}{ Unsur makro } \\
\hline 10. & Bahan organik & $\%$ & 27 & 58 \\
\hline 11. & Nitrogen & $\%$ & 0,40 & - \\
\hline 12. & Karbon & $\%$ & 9,80 & 32 \\
\hline 13. & Fosfor ( P205) & $\%$ & 0,10 & - \\
\hline 14. & C/N-rasio & & 10 & 20 \\
\hline 15 & Kalium (K2O) & $\%$ & 0,20 & $*$ \\
\hline 16 & Unsur mikro & & $*$ & \\
\hline 17 & Arsen & $\mathrm{mg} / \mathrm{kg}$ & $*$ & 13 \\
\hline 18 & Kadnium (CD) & $\mathrm{mg} / \mathrm{kg}$ & $*$ & 3 \\
\hline 19 & Cobar $(\mathrm{CO})$ & $\mathrm{mg} / \mathrm{kg}$ & $*$ & 34 \\
\hline 20 & Kromium (Cr) & $\mathrm{mg} / \mathrm{kg}$ & $*$ & 210 \\
\hline 21 & Tembaga (Cu) & $\mathrm{mg} / \mathrm{kg}$ & * & 100 \\
\hline 22 & Merkuri (Hg) & $\mathrm{mg} / \mathrm{kg}$ & $*$ & 0,8 \\
\hline 23 & Nikel (Ni) & $\mathrm{mg} / \mathrm{kg}$ & $*$ & 62 \\
\hline 24 & Timbal $(\mathrm{Pb})$ & $\mathrm{mg} / \mathrm{kg}$ & $*$ & 150 \\
\hline 25 & Selamium (Se) & $\mathrm{mg} / \mathrm{kg}$ & * & 2 \\
\hline 26 & Seng $(Z n)$ & $\mathrm{mg} / \mathrm{kg}$ & $*$ & 500 \\
\hline 27 & Unsur lain & & & \\
\hline 28 & Kalsium & $\%$ & $*$ & 25,50 \\
\hline 29 & Magnesium (Mg) & $\%$ & $*$ & 0,60 \\
\hline 30 & Besi (Fe) & $\%$ & $*$ & 2,00 \\
\hline 31 & Alumunium (Al) & $\%$ & $*$ & 2,20 \\
\hline 32 & Mangan (Mn) & $\%$ & $*$ & 2,10 \\
\hline 33 & Bakteri & & & \\
\hline 34 & Fecal coli & MPN/gr & & 1000 \\
\hline 35 & Salmonella sp & MPN/4gr & & 3 \\
\hline \multicolumn{5}{|c|}{$\begin{array}{c}\text { Keterangan : *Nilainya lebih besar dari minimum atau lebih } \\
\text { kecil dari maksimum }\end{array}$} \\
\hline
\end{tabular}

\section{METODELOGI PENELITIAN}

Penelitian ini menggunakan metode komparatif, yaitu membandingkan kadar $\mathrm{P}, \mathrm{K}$ dan rasio $\mathrm{C} / \mathrm{N}$ antara kompos yang dihasilkan dengan aktivator EM4 dan kompos yang dihasilkan dengan kotoran sapi. Dalam flow chart digambarkan proses pembuatan kompos berbahan sampah organik menjadi pupuk kompos yang siap pakai.

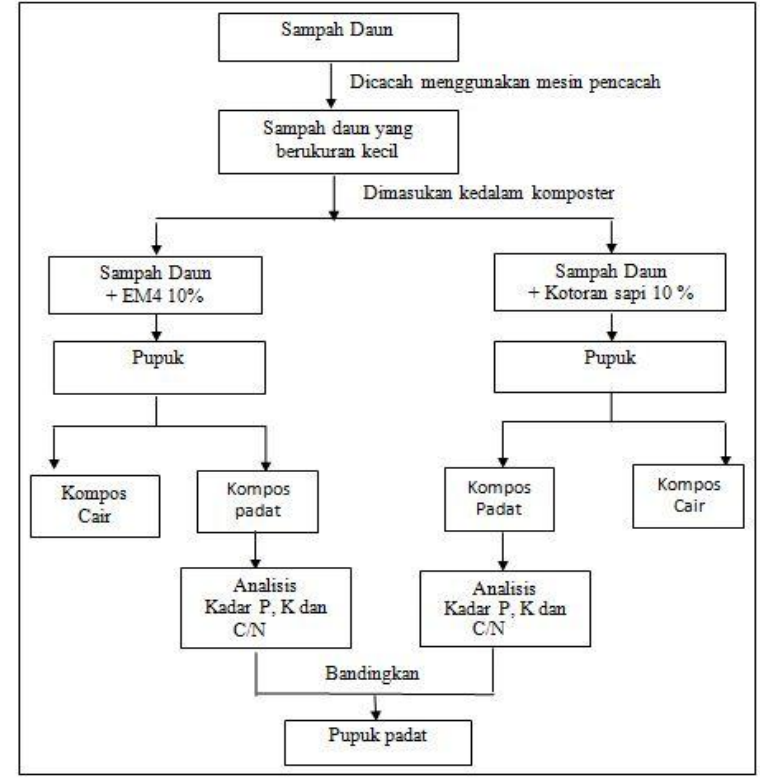

Gambar 1. Flow chart pembuatan pupuk kompos

\section{HASIL DAN PEMBAHASAN}

Tabel 3 memperlihatkan perbandingan hasil pembuatan pupuk kompos menggunakan EM4 dan kotoran sapi.

Dapat disimpulkan bahwa perbandingan hasil akhir pupuk kompos menggunakan aktivator EM4 dan pupuk daun yangmenggunakan kotoran sapi lebih memenuhi standar SNI pupuk yang menggunakan tambahan kotoran sapi dibandingan dengan pupuk kompos daun yang menggunakan aktivator EM4.

\section{Hasil Pengamatan Sifat Fisik Kompos}

Berdasarkan pengamatan yang telah dilakukan dalam penelitian ini berupa tekstur, warna, bau yang terdapat dari kompos. Pada hari pertama atau awal pengomposan testur kedua kompos, kompos masih berupa cacahan daun kering. Warna kompos masih menyerupai warna daun kering coklat dan untuk bau masih berbau daun. Kemudian selama proses pengomposan kedua kompos tersebut terjadi perubahan fisik diantaranya yaitu dengan perubahan segi warna menjadi coklat kehitaman dan tekstur yang terlihat kurang lebih hancur untuk bau cenderung menyerupai bau tanah di hari ke-15 untuk kompos yang mengunakan campuran kotoran sapi. Berbeda dengan kompos yang mengunakan aktivator EM4 di hari ke-15 baunya cenderu ng menyerupai bau mentega. Diperoleh hasil bahwa kompos dengan mengunakan kotoran sapi berwarna hitam kehitaman dan berbau tanah. Sedangkan dengan penggunaan aktivator (EM4) hasilnya berwarna coklat kehitaman, dan berbau tanah. Pada hari terakhir pengomposan menunjukkan ciri kematangan masing-masing kompos tersebut sampah daun yang menggu nakan campuran kotoran sapi secara fisik yaitu 
warnanya telah berubah menjadi hitamkehitaman di hari ke 20 bau tanah dengan testur hancur sedikit halus. Berbeda dengan sampah daun mengunakan aktivator EM4 secara fisik warna kompos coklat kehitaman teksturnya hancur, bau cenderung menjadi bau humus/tanah ditunjukan pada Gambar 2 dibawah ini.

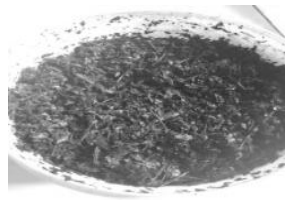

(a)

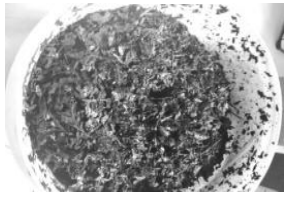

(c)

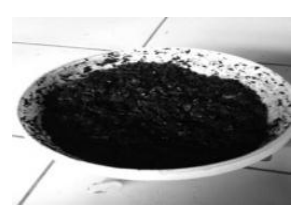

(b)

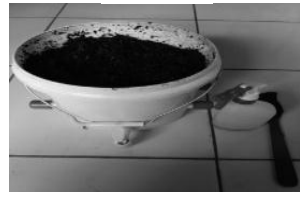

(d)
Gambar 2. Proses pengomposan

Keterangan gambar:

(a) Hari ke-0 kompos daun kotoran sapi

(b) Hari ke-20 kompos daun kotoran sapi

(c) Hari ke-0 kompos daun aktivator EM4

(d) Hari ke-20 kompos daun aktivator EM4
Tabel 4. Hasil Pengujian Kualitas Pupuk

\begin{tabular}{|c|c|c|c|c|}
\hline No. & Parameter & Satuan & Min & Maks \\
\hline 1. & Kadar air & $\%$ & - & 50 \\
\hline 2. & Temperatur & ${ }^{0} \mathrm{C}$ & & $\begin{array}{l}\text { Suhu air } \\
\text { tanah }\end{array}$ \\
\hline 3. & Warna & & & Kehitaman \\
\hline 4. & Bau & & & Berbau tanah \\
\hline 5. & Ukuran partikel & $\mathrm{Mm}$ & 0,55 & 25 \\
\hline 6. & $\begin{array}{l}\text { Kemampuan } \\
\text { ikat air }\end{array}$ & $\%$ & 58 & - \\
\hline 7. & $\mathrm{Ph}$ & & 6,80 & 7,49 \\
\hline 8. & Bahan asing & $\%$ & $*$ & 1,5 \\
\hline \multicolumn{5}{|c|}{ Unsur makro } \\
\hline 10. & Bahan organik & $\%$ & 27 & 58 \\
\hline 11. & Nitrogen & $\%$ & 0,40 & - \\
\hline 12. & Karbon & $\%$ & 9,80 & 32 \\
\hline 13. & Fosfor ( P2O5) & $\%$ & 0,10 & - \\
\hline 14. & C/N-rasio & & 10 & 20 \\
\hline 15 & Kalium (K2O) & $\%$ & 0,20 & * \\
\hline 16 & Unsur mikro & & $*$ & \\
\hline 17 & Arsen & $\mathrm{mg} / \mathrm{kg}$ & * & 13 \\
\hline 18 & Kadnium (CD) & $\mathrm{mg} / \mathrm{kg}$ & * & 3 \\
\hline 19 & Cobar (CO) & $\mathrm{mg} / \mathrm{kg}$ & * & 34 \\
\hline 20 & Kromium (Cr) & $\mathrm{mg} / \mathrm{kg}$ & * & 210 \\
\hline 21 & Tembaga (Cu) & $\mathrm{mg} / \mathrm{kg}$ & * & 100 \\
\hline 22 & Merkuri (Hg) & $\mathrm{mg} / \mathrm{kg}$ & * & 0,8 \\
\hline 23 & Nikel (Ni) & $\mathrm{mg} / \mathrm{kg}$ & * & 62 \\
\hline 24 & Timbal (Pb) & $\mathrm{mg} / \mathrm{kg}$ & * & 150 \\
\hline 25 & Selamium (Se) & $\mathrm{mg} / \mathrm{kg}$ & * & 2 \\
\hline 26 & Seng (Zn) & $\mathrm{mg} / \mathrm{kg}$ & $*$ & 500 \\
\hline 27 & Unsur lain & & & \\
\hline 28 & Kalsium & $\%$ & $*$ & 25,50 \\
\hline 29 & $\begin{array}{l}\text { Magnesium } \\
\text { (Mg) }\end{array}$ & $\%$ & $*$ & 0,60 \\
\hline 30 & Besi (Fe) & $\%$ & * & 2,00 \\
\hline 31 & Alumunium (Al) & $\%$ & * & 2,20 \\
\hline 32 & Mangan (Mn) & $\%$ & $*$ & 2,10 \\
\hline 33 & Bakteri & & & \\
\hline 34 & Fecal coli & $\begin{array}{c}\mathrm{MPN} / \mathrm{g} \\
\mathrm{r}\end{array}$ & & 1000 \\
\hline 35 & Salmonella sp & $\begin{array}{c}\mathrm{MPN} / 4 \\
\mathrm{gr}\end{array}$ & & 3 \\
\hline
\end{tabular}

Tabel 3. Hasil Pengujian Kualitas Pupuk

\begin{tabular}{|c|c|c|c|c|c|c|}
\hline \multirow{2}{*}{ No } & \multirow{2}{*}{ Parameter } & \multirow{2}{*}{ Satuan } & \multicolumn{2}{|c|}{ SNI Kualitas Kompos } & \multirow{2}{*}{$\begin{array}{c}\text { Hasil } \\
\text { Pengujian Pupuk } \\
\text { Kotoran Sapi }\end{array}$} & \multirow{2}{*}{$\begin{array}{c}\text { Hasil } \\
\text { Pengujian Pupuk } \\
\text { EM4 }\end{array}$} \\
\hline & & & Minimum & Maksimum & & \\
\hline 1 & Kadar air & $\%$ & & 50 & 14,11 & 14,17 \\
\hline 2 & Temperatur & ${ }^{0} \mathrm{C}$ & & $\begin{array}{c}\text { Suhu air } \\
\text { tanah }\end{array}$ & 28 & 28 \\
\hline 3 & Warna & & & Kehitaman & Kehitaman & Coklat kehitaman \\
\hline 4 & Bau & & - & Berbau tanah & Berbau tanah & Berbau tanah \\
\hline 5 & $\mathrm{pH}$ & & 6,80 & 7,49 & 7 & 6 \\
\hline 6 & C-organik & $\%$ & 9,80 & 32 & 32,15 & 31,94 \\
\hline 7 & $\mathrm{~N}$ & $\%$ & 0,40 & & 1,63 & 1,30 \\
\hline 8 & Rasio C/N & & 10 & 20 & 20 & 25 \\
\hline 9 & fosfor & $\%$ & & $*$ & 0,21 & 0,12 \\
\hline 10 & Kalium & $\%$ & 0,10 & $*$ & 0,44 & 0,47 \\
\hline
\end{tabular}




\section{KESIMPULAN DAN SARAN}

\section{Kesimpulan}

Berdasarkan hasil penelitian yang

dilaksanakan dapat disimpulkan bahwa:

1. Pupuk daun yang menggunakan aktivator EM4 memiliki nilai pH 6, dan kadar P 0,12\%, kadar $\mathrm{K}$ 0,47\%, dengan nilai C-organik $31,94 \%$, nilai $\mathrm{N}$ sebesar $1,30 \%$ dan rasio $\mathrm{C} / \mathrm{N}$ 25, selain itu warna pupuk kompos daun yang menggunakan campuran EM4 berwarna coklat kehitaman, dan berbau tanah.

2. Pupuk daun yang menggunakan tambahan kotoran sapi memiliki nilai $\mathrm{pH} \mathrm{7,} \mathrm{dengan}$ kadar $\mathrm{P} 0,21 \%$, kadar $\mathrm{K}$ sebesar 0,44\%, dengan nilai C-organik $32,15 \%$ dan nilai $\mathrm{N}$ $1,63 \%$, dengan rasio $\mathrm{C} / \mathrm{N} 20$ pupuk daun yang menggunakan kotoran sapi berwarna hitam kehitaman, dan berbau tanah.

Berdasarkan data diatas maka dapat disimpulkan bahwa perbandingan hasil akhir pupuk kompos yang menggunakan kotoran sapi lebih memenuhi standar dibandingkan dengan aktivator EM4.

\section{Saran}

Untuk penelitian berikutnya terdapat

beberapa saran, diantaranya :

1. Menggunakan sampel lain seperti limbah/sampah sayuran/buah-buahan yang berhubungan dengan pupuk kompos, agar dapat menyempurnakan penelitian ini sebagai tambahan pengetahuan dan wawasan dalam pembuatan pupuk kompos

2. Menggunakan metode lain seperti metode aerob. dalam pembuatan kompos padat sehingga dapat menghasilkan pupuk kompos yang berkualitas baik

\section{DAFTAR PUSTAKA}

Harapan, Hari Anggari.2000.Ekologi. Inggris: Penerbit Balai Pustaka Jakarta.

Indriani, Hety Yovita.2011.Pembuatan Pupuk Kilat. Jakarta: Penerbit Penebar Swadaya.

Kartika, Gema Juang.2013. Bertanam dan Sayuran Organik. Jakarta: Penerbit Penebar Swadaya.

Widarti, Nining.2015. Pengruh Rasio C/N Bahan Baku Pada Pembuatan Kompos Dari Kubis Dan Kulit Pisang, Jurnal Integrasi Proses Vol. 5, No. 2, 77

Suryati, Teti.2014. Bebas Sampah dari Rumah. Penerbit PT Agromedia Pustaka

SNI 19-7030-2004. Spesifikasi kompos dari sampah organik domestic http://inswa.or.id/wp-

content/uploads/2012/07/Spesifikasi-komposSNI.pdf.diakses pada 3 januari 2017.

http://pvtpp.setjen.pertanian.go.id/download/per mentan-28-2009/pusat perlindungan varietas tanaman dan perizinan pertanian http://www.bbpp-

lembang.info/index.php/arsip/artikel/artikelpertanian/722-menerapkan-pertanian-akrablingkungan-dengan-em-4-merupakanteknologi-alternatif-memperbaiki-tanah-yangsakit 